\title{
A new species of Mouse Spider (Actinopodidae, Missulena) from the Goldfields region of Western Australia
}

\author{
Volker W. Framenau ${ }^{1,2,3,4}$, Danilo Harms ${ }^{4}$ \\ 1 Phoenix Environmental Sciences Pty Ltd, 1/511 Wanneroo Road, Balcatta, Western Australia 6021, Australia \\ 2 School of Animal Biology, The University of Western Australia, 35 Stirling Highway, Crawley, Western Australia 6009, Australia \\ 3 Department of Terrestrial Zoology, Western Australian Museum, Locked Bag 49, Welshpool DC, Western Australia 6986, Australia \\ 4 Zoological Museum, Center of Natural History, University of Hamburg, Martin-Luther-King-Platz 3, 20146 Hamburg, Germany
}

http://zoobank.org/6FB6F2EA-4F6F-44ED-A644-DB99C9411E36

Corresponding author: Volker W. Framenau (volker.framenau@phoenixenv.com.au)

Received 23 June 2017

Accepted 18 August 2017

Published 22 December 2017

Academic editor:

Martin Husemann

\section{Key Words}

\section{Taxonomy}

systematics

barcoding

COI

Mygalomorphae

\begin{abstract}
A new species of Mouse Spider (family Actinopodidae Simon, 1892), Missulena harewoodi, is described from near the City of Kalgoorlie-Boulder in the Goldfields region of Western Australia. It differs from all other Missulena species by the unusual light grey colouration of the abdomen in combination with small body size and shiny carapace. A phylogenetic analysis of a fragment (658 bp) of the COI barcoding gene places $M$. harewoodi sp. n. in a clade with four Missulena species from the Pilbara region of Western Australia, more than $900 \mathrm{~km}$ away. Missulena harewoodi $\mathbf{s p .} \mathbf{n}$. is one of the many species in this genus that are currently only known from a single, or a very limited number of specimen, highlighting the paucity of fauna collections in many arid regions of Australia and the difficulties in sampling these cryptic spiders.
\end{abstract}

\section{Introduction}

The spider family Actinopodidae Simon, 1892 has a Gondwanan distribution with species found in Australia and South America (World Spider Catalog 2017). In Australia, these spiders are commonly called Mouse Spiders and widely known because they can be quite large (up to 3-4 cm in body size) and superficially resemble the venomous Funnel-web Spiders (family Hexathelidae Simon, 1892). Some species may have a potent venom although spiders appear to generally apply a dry bite in defense (e.g. Isbister 2004; Isbister and Gray 2004; Rash et al. 2000). The colour patterns in male Missulena belong to the most spectacular amongst all mygalomorph spiders. Most striking are the sometimes bright red fangs and/or carapace in males, iridescent blue abdomens, or an abdomen with light colour patterns (Framenau et al. 2014). Vivid colouration with typical warning colours such as red possibly relates to the diurnal activity of mate-searching Missulena males, whereas the majority of males in other mygalomorph families are strictly nocturnal (Harms and Framenau 2013).

The Australian fauna in this family currently comprises 16 species in the single genus Missulena Walckenaer, 1805 (Miglio et al. 2014; World Spider Catalog 2017). However, species-level diversity in this genus is clearly much higher, with dozens of undescribed species identified in recent barcoding analyses (e.g. Castalanelli et al. 2014). The fauna of Western Australia, where 14 of the 16 described species occur (Miglio et al. 2014), is particularly diverse. Recent barcoding projects focusing on the Pilbara region in the northwest of the state recovered 13 distinct genetic clades, only five representing described species (Castalanelli et al. 2014). The two most recent taxonomic studies (Harms and Framenau 2013, Miglio et al. 2014) on Missulena developed a protocol for the description of spe- 
Table 1. Missulena specimen sequenced for this study.

\begin{tabular}{|c|c|c|c|c|c|c|}
\hline $\begin{array}{c}\text { WAM } \\
\text { registration }\end{array}$ & $\begin{array}{c}\text { Identification } \\
\text { (WAM database) }\end{array}$ & Sex & Location & Latitude & Longitude & $\begin{array}{c}\text { GenBank } \\
\text { accession no. }\end{array}$ \\
\hline $\mathrm{T} 142820$ & M. harewoodi $\mathrm{sp} . \mathrm{n}$. & male & $20 \mathrm{~km} \mathrm{E}$ of Kalgoorlie & -30.744722 & 121.566944 & MF693350 \\
\hline T124777 & M. 'DNA02' & immature & $5 \mathrm{~km} \mathrm{WNW}$ of Mt Farquhar & -22.282259 & 116.720715 & MF693351 \\
\hline T128168 & M. 'DNA03' & immature & $100 \mathrm{~km} \mathrm{~W}$ of Tom Price & -22.538166 & 116.869921 & MF693352 \\
\hline $\mathrm{T} 128170$ & M. 'DNA03' & immature & $100 \mathrm{~km} \mathrm{~W}$ of Tom Price & -22.708678 & 116.850098 & MF693353 \\
\hline T128154 & M. 'DNA03' & immature & $100 \mathrm{~km} \mathrm{~W}$ of Tom Price & -22.6009787 & 117.028344 & MF693354 \\
\hline
\end{tabular}

cies after several decades of taxonomic neglect and added six new species to the Australian fauna. They also provided an updated key to the males of all Australian species (Harms and Framenau 2013; Miglio et al. 2014).

Recent collections as part of environmental assessment studies in the semi-arid Goldfields region of Western Australia recovered a small male of Missulena with the feature of light grey abdomen both as live (VWF pers. obs.) and preserved (Fig. 1A) specimen, another facet of the striking colour variations present within this genus. Light abdomen discolourations have previously only been described from two larger species with very different distribution in Australia (M. pruinosa Levitt-Gregg, 1966 from tropical northern Australia and M. bradleyi Rainbow, 1914 from the subtropical/temperate eastern parts of the country), but the current species is smaller and the pattern is more pronounced.

In this paper, we describe this unusual species of Missulena based on male morphology. A phylogenetic analysis of a fragment of the COI barcoding gene is used to explore the systematic position of this species and consolidate its taxonomic concept developed based on morphology. In documenting this species, we hope to raise further awareness for the Australian Mouse Spiders by documenting another morphological rarity in its diverse fauna.

\section{Methods}

Morphology. The holotype of $M$. harewoodi sp. no. was examined in $75 \%$ ethanol under Leica M205C and M80 stereomicroscopes. Digital images were taken using a Leica DFC 295 digital camera attached to the Leica M205C stereomicroscope controlled by the Leica Application Suite Version 3.8. The images were edited and formatted in Adobe Photoshop CC, release 2017. For measurement protocols and overall format of the description please see Griswold and Ledford (2001), Harms and Framenau (2013) and Miglio et al. (2014). Abbreviations for morphological characters are as follows: (EL) embolar lamella, (DET) distal embolar tooth, (BEI) basal embolar intumescence, (PME) posterior median eyes, (PLE) posterior lateral eyes, (ALE) anterior lateral eyes, (AME) anterior median eyes, (MOQ) median ocular quadrangle, (OAL) ocular area length, (OAW) ocular area width. Leg spination: (d) dorsal, (pv) proventral, (rv) retroventral, (v) ventral. WAM refers to the Western Australian Museum. The nomenclature of undescribed species follows the designation as provided by the Western Australian Museum (WAM) or Castalanelli et al. (2014).

Molecular analyses. Sequencing of the mitochondrial $\mathrm{CO} 1$ gene of the holotype followed the protocol described in a previous study (Harms and Framenau 2013). Phylogenetic analyses were undertaken on an alignment comprising all 84 Missulena sequences from previous studies and available on GenBank (Castalanelli et al. 2014; Harms and Framenau 2013), four specimens that were sampled in Western Australia since then and the holotype of $M$. harewoodi sp. n. (Table 1). COI sequences of a single specimen of Euagrus chisoseus Gertsch, 1939 (Dipluridae Simon, 1889) and five unidentified specimens of Conothele Thorell, 1878 (family Ctenizidae Thorell, 1887) were extracted from GenBank and included in the analyses as outgroups. A barcoding threshold of 9.5\% pairwise sequence divergence was used for species delineation at a molecular level (Castalanelli et al. 2014). Phylogenetic analyses were executed using MrBayes Version 3.2.1 for Macintosh (Ronquist et al. 2012), with the GTR $+\mathrm{I}+\mathrm{G}$ model of nucleotide substitution suggested by MrModeltest Version 3.7 (Posada and Crandall 1998) for an unpartitioned dataset. Four Markov chain Monte Carlo (MCMC) chains were run for 40,000,000 generations, sampling every 1,000 generations and discarding the first of $25 \%$ of sampled trees as 'burnin'. FigTree version 1.4.3 (Rambaut 2016) was used to visualise and edit the tree.

\section{Systematics}

\section{Family Actinopodidae Simon, 1892}

\section{Missulena Walckenaer, 1805}

Missulena Walckenaer, 1805: 8. Type species: Missulena occatoria Walckenaer, 1805, by monotypy.

Eriodon Latreille, 1806: 85. Type species: Eriodon occatorius Latreille, 1806, by monotypy.

\section{Missulena harewoodi sp. $\mathrm{n}$.}

http://zoobank.org/3FE6A340-C871-45B8-ACFC-E9677586C417 Figs $1 \mathrm{~A}-\mathrm{G}, 2 \mathrm{~A}-\mathrm{F}, 4$

Type material. AUSTRALIA: Western Australia: holotype male, $20 \mathrm{~km}$ East of Kalgoorlie, 30 44'41'S, 12134'01'E, 14-16 April 2015, Greg Harewood, dry 

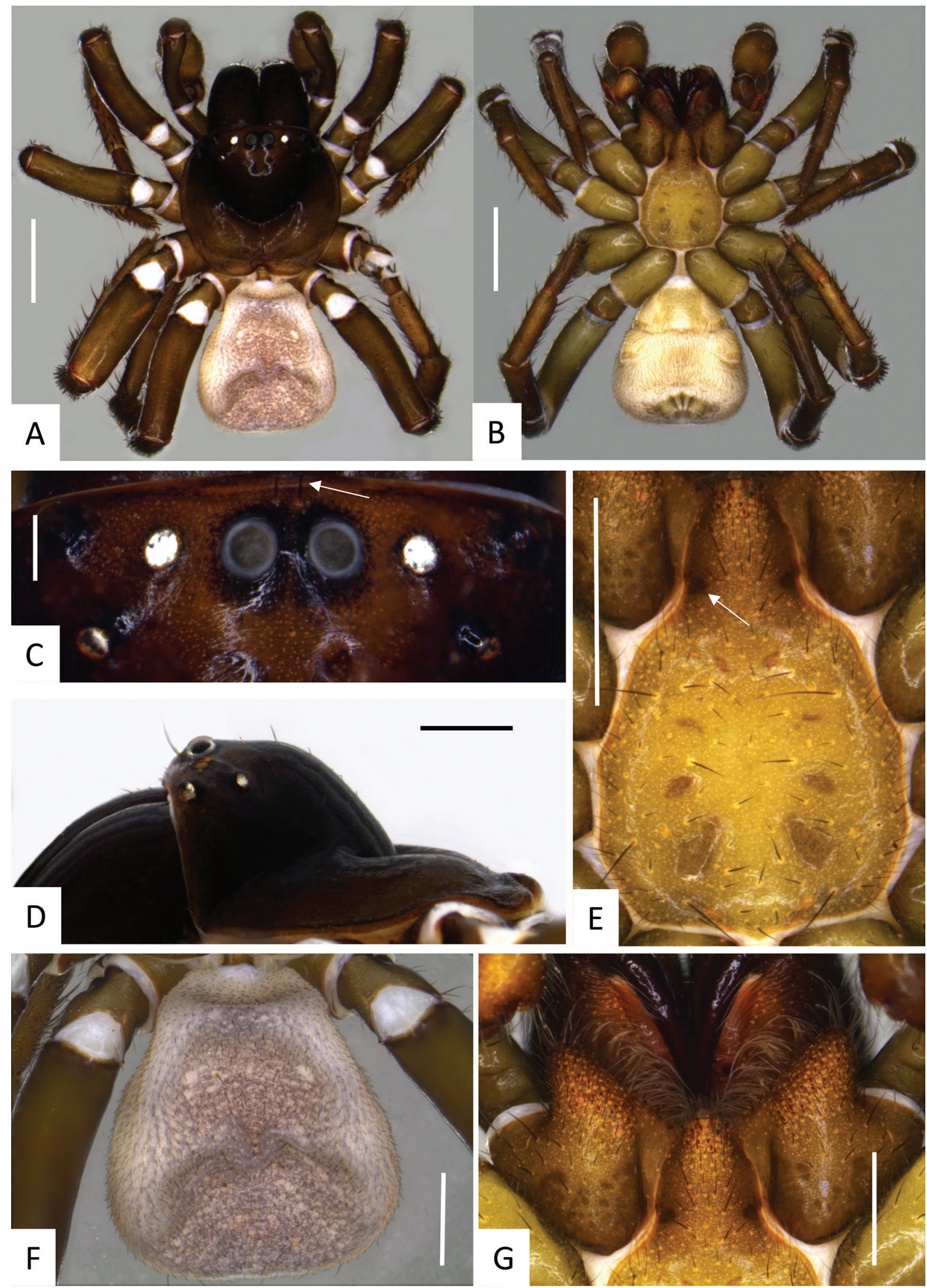

Figure 1. Missulena harewoodi sp. n., male holotype (WAM T142820) A, habitus, dorsal view; B, ventral view; C, eye region, dorsal view; D, carapace, lateral view; E, sternum, ventral view; F, abdomen, dorsal view; G, maxillae and labium, ventral view. Scale bars: $\mathbf{A}, \mathbf{B}-2.0 ; \mathbf{C}-0.1 ; \mathbf{D}, \mathbf{E}, \mathbf{F}-1.0 ; \mathbf{G}-0.5$. Arrows point to pair of anterior setae (C) and labio-sternal sigillae (E) (see text). 
pitfall trap, Goldfields Blackbutt low woodland over open scrub on loam (WAM T142820).

Etymology. The specific epithet is a patronym in honour of Greg Harewood, the collector of the type specimen.

Diagnosis. The colouration of the holotype of $M$. harewoodi $\mathrm{sp}$. $\mathrm{n}$. is most similar to $M$. pruinosa due to the light dorsal discolouration of the abdomen, but the species differs in the lower number of spines of the rastellum (three $v s$ ten), smaller size (male body length 8.0 mm vs $12.5 \mathrm{~mm}$ ) (measurements from Faulder 1995a) and narrower pedipalp tibia. Male Missulena bradleyi also have a light pattern on the dorsal side of the abdomen, but it is restricted to an anterior light blue patch and the species is also larger (male body length $8.0 \mathrm{~mm}$ vs $10.9 \mathrm{~mm}$ ) (measurements from Faulder 1995a). Otherwise, somatic morphology most closely resembles three species with a brown carapace, M. melissae Miglio, Harms, Framenau \& Harvey, 2014, M. faulderi Harms \& Framenau, 2013 and M. rutraspina Faulder, 1995, but $M$. harewoodi sp. n. differs considerably in the colour pattern of the abdomen of both live and preserved specimens (brown in M. melissae, grey-brown in M. faulderi and blue-grey in $M$. rutraspina) and the much smoother carapace (Faulder 1995b; Harms and Framenau 2013; Miglio et al. 2014).

Description. Adult male, based on holotype (WAM T142820). Small mygalomorph spider (total length 8.0).

Colour: Carapace glabrous brown to dark brown (Fig. 1A); dark brown around PME (Fig. 1C); chelicerae and fangs glabrous, brown to reddish-brown (Figs. 1D, G); abdomen dorsally pale whitish laterally, medially light grey (Figs 1A, F); ventrally pale yellowish-brown (Fig. 1B); sternum yellowish-brown, darker towards margins, sigilla light brown (Fig. 1B, E); labium and maxillae light brown, with yellow-brown spots (Fig. 1G); legs glabrous brown, ventrally with olive tinge (Figs 1A, B); spinnerets olive gray (Fig. 2F).

Carapace: 3.52 long, 3.74 wide; clypeus 0.19; caput and eye region elevated (Fig. 1D); pars cephalica smooth, pars thoracica with bands of fine, radial fissures.

Eyes: OQ 3.28 times wider than long, OAW 2.13; OAL 0.65 ; width of posterior eye group 1.85; PME 0.178; PLE 0.18; ALE 0.23; AME 0.30; AME inter-distance 0.15; AME to ALE 0.83; AME to PME 0.21; PLE to ALE 0.40; PLE to PME 0.42; PME inter-distance 1.20; PME to ALE 0.49; two black setae anterior of AME (Fig. 1C).

Chelicerae: 1.62 long, 1.03 wide; with few short silvery setae medially; rastellum developed, slightly pronounced, consisting of a sclerotised process with 3 (left 4) strong conical spines and 12-14 disordered setae (Fig. 2E), 10-14 long setae extend forward from anterior margin of each chelicera and cover base of fang; inner margin of cheliceral furrow with 3 rows of teeth (Fig. 1G); prolateral (inner) row with ca. 9 teeth; intermediate row with 6 proximal, small spaced teeth; retrolateral (outer) row with 2 proximal teeth.

Maxillae: 1.56 long; 1.10 wide (Fig. $1 G$ ), with ca. 40 pointed cuspules along entire anterior margin.
Labium: ca. 0.82 long, 0.70 wide; conical, 11 pointed cuspules anteriorly (Figs 1G); labiosternal suture poorly developed; a pair of sigilla near labiosternal suture (Fig. 1E).

Sternum: 2.17 long, 2.00 wide; pear-shaped and rebordered (Fig. 1E), with dark setae of varying length, arranged irregularly but denser laterally and towards labium; 4 pairs of sigilla located more than three times their length from the border of the sternum, anterior and second pair (anterior-posterior) smallest and poorly defined, third pair bigger than 2 anterior pairs and poorly defined; posterior pair biggest, roughly oval and well defined, 3 posterior sigilla slightly depressed.

Abdomen: 3.58 long, 3.23 wide; roughly oval (but collapsed through preservation) (Fig. 1A, F); 4 spinnerets (Fig. 2F), PLS 0.52 long, 0.43 wide, apical segment domed; PMS 0.35 long, 0.16 wide at base.

Pedipalp: Length of trochanter 0.76 , femur 1.62, patella 1.08 , tibia 2.12 , tarsus 0.86 ; tibia with irregular black setae, densest ventrally (Fig. 2A-C); bulb pyriform (Fig. 2A-C), two strongly sclerotised sections connected by a velar median structure ("haematodocha", Fig. 2C); embolus very slightly curved, reaches to half tibia length, with an intumescence in proximal region (BEI), a strong curvature in the duct in prolateral view, tapering and slightly twisted medially (Fig. 2C); embolus tip rounded triangular, with a lamella (EL) poorly developed and no prominent tooth (DET) (Fig. 2D).

Legs: With few brown setae, ventral setae of tibiae and metatarsi generally much longer and thicker than dorsal setae; dorsal; preening comb distal in tarsi, very small and plain; metatarsi and tarsi I and II ascopulate, metatarsi (along distal half) and tarsi (along whole length) of legs III and IV densely scopulate . Leg measurements: Leg I: femur 2.37 , patella 1.54 , tibia 1.84 , metatarsus 1.46 , tarsus 0.97 , total 8.18 . Leg II: $2.54,1.44,1.46,1.59,0.95$, 7.98. Leg III: $2.68,1.49,1.29,1.17,1.28,8.11$. Leg IV: $3.14,1.70,2.10,3.29,1.16,11.39$. Formula 4123.

Trichobothria: Arranged in discontinuous rows; tibiae I-II with 2 rows of 3 in retrodorsal and prodorsal position, respectively; tibiae III with 1 rows of 2 in retrolaterodorsal; tibiae IV with 2 rows, the first row with 3 in retrolatero-dorsal and the second row with 2 in proximolateral position; metatarsi with 3 in proximo-dorsal row, tarsi I with 2 in proximo-dorsal row, tarsi II with 3, III+IV with 4 medio-dorsally, respectively.

Leg spination: Pedipalp aspinose; leg I: tibia rv1-1-0, v3-3-7, pv1-2-0, d0-0-0; metatarsus rv2-1-1, v2 $-3-5$, pv0 $-0-0, \mathrm{~d} 0-0-0$; tarsus rv1-4-3, v2 $-7-3$, pv2-2-2, d0-0-0; leg II: tibia $\mathrm{rv0}-0-0, \mathrm{v} 0-0-0$, pv0 $-1-0, \quad \mathrm{~d} 0-0-0 ; \quad$ metatarsus $\mathrm{rv} 0-0-0, \quad \mathrm{v} 0-0-0$, pv0-0-0, d0-0-0; tarsus rv3-5-4, v1-2-2, pv1-3-2, $\mathrm{d} 0-0-0$; leg III: tibia rv0-0-0, v0-3-2, pv2-2-2, $\mathrm{d} 2-1-3$; metatarsus rv2-2-3, v0-0-0, pv3-3-4, d8-4-2; tarsus rv3-5-4, v0-0-1, pv1-3-4, d0-2-2; leg IV: tibia rv0-2-0, v2-4-4, pv1-1-2, d3-0-0; metatarsus rv1-3-2, v0-0-0, pv1-3-4, d0-0-1; tarsus rv4-9-13, v0-0-1, pv1-4-6, d0-0-2; patellae I with ca. 10 rasp prolaterally, II with 2 rasp prolaterally, III with ca. 40 

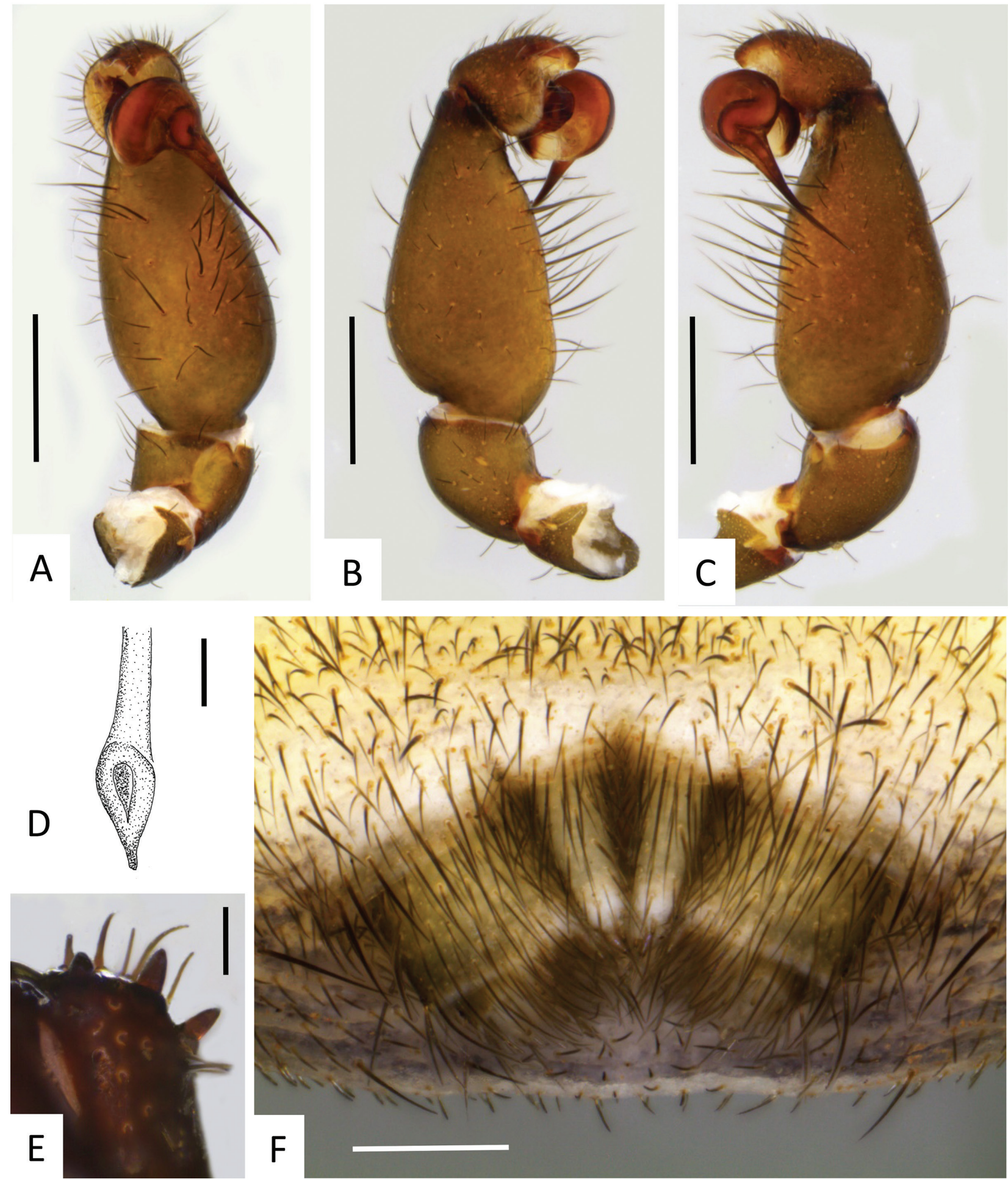

Figure 2. Missulena harewoodi sp. n., male holotype (WAM T142820) A, left pedipalp, ventral view; B, prolateral view, C, retrolateral view; D, embolus tip, ventral view; E, rastellum of left chelicerae, ventral view; F, spinnerets, ventral view. Scale bars: $\mathbf{A}, \mathbf{B}, \mathbf{C}-1.0$; $\mathbf{D}-0.05 ; \mathbf{E}-0.1 ; \mathbf{F}-0.2$.

rasps prolaterally to dorsal, patella IV with ca. 10 rasps prolaterally and proximo-dorsally.

Phylogenetic analyses. Our phylogenetic analyses places M. harewoodi sp. n. as sister taxon to an undescribed Missulena species from the Pilbara region in Western Australia, Missulena 'DNA02' (WAM T124777) (Fig. 3; Table 1), although this relationship is not well supported. Sequence divergence between both specimens is $14.5 \%$, which is considerably larger than the current operational sequence divergence of $9.5 \%$, employed to differentiate species in the Actinopodidae (Castalanelli et al. 2014). Morphological comparison between both species is not possible as the Pilbara species is represented by a single juvenile specimen. Missulena harewoodi sp. 


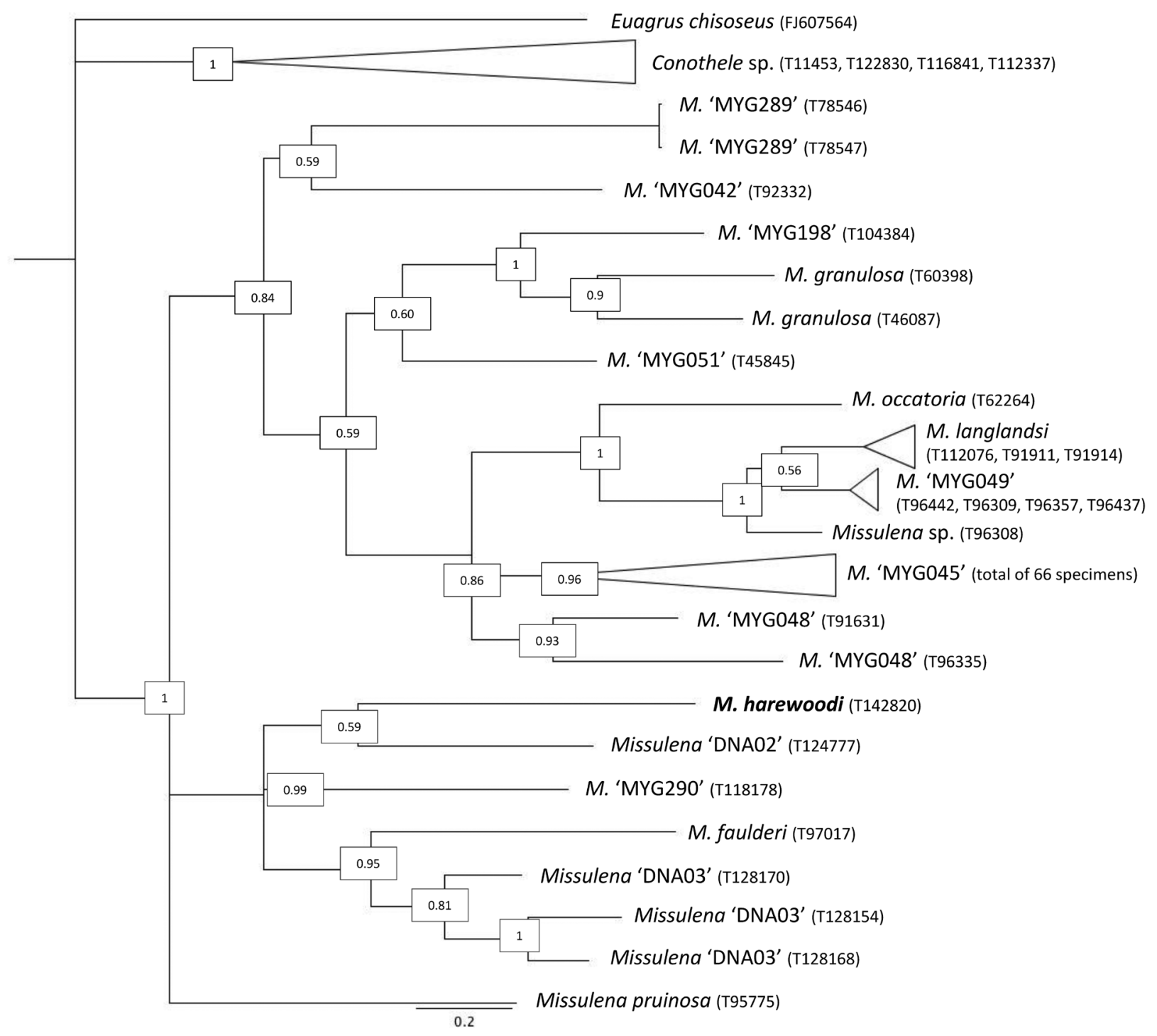

Figure 3. Topology of Missulena species based on COI (fragment of $658 \mathrm{bp}$ ). Nodal support is indicated in squares (posterior probabilities). Branches of more of three specimens of the same species are collapsed. Morphotype designations of undescribed species reflects those databased at the Western Australian Museum. See Castalanelli et al. (2013) for details on the 'MYG'-coding system and museum registration numbers.

n. from the Goldfields nests within a clade of three putative new species, Missulena 'DNA02', 'DNA03' and 'MYG290' and Missulena faulderi, that are all from the Pilbara bioregion of Western Australia, situated more than $900 \mathrm{~km}$ north-west of the City of Kalgoorlie-Boulder (Fig. 3). The Pilbara is geologically, floristically and climatically distinct from the Goldfields and it is unclear whether the results of our analyses are caused by taxon bias in the set of DNA sequences or reflect a true biogeographic pattern. Only more comprehensive analyses with additional representatives from southern and central Western Australia and including additional genes can clarify the phylogeographic patterns in Missulena.

Distribution. Missulena harewoodi sp. n. is currently only known known from the type locality, ca. $20 \mathrm{~km}$ East of the City of Kalgoorlie-Boulder in the Goldfields region of Western Australia (Fig. 4).

Habitat. The type specimen was collected alive in a 10-litre, dry bucket pitfall trap targeting vertebrates. The collecting site is described as Goldfields Blackbutt (Eucalyptus lesouefii) low woodland over open scrub on loamy soil (G. Harewood, personal communication to VWF). Similar to many other Missulena species, M. harewoodi sp. n. appears to mature in autumn (collected in April), contradicting the assumption that many mygalomorph spiders in arid and semi-arid Australia reproduce in the months with highest rainfall (e.g. January/February in the Goldfields near Kalgoorlie) (BoM 2017; EPA 2016).

Remarks. Missulena harewoodisp. $\mathrm{n}$. is the seventeenth named species of this genus in Australia and within a radi- 


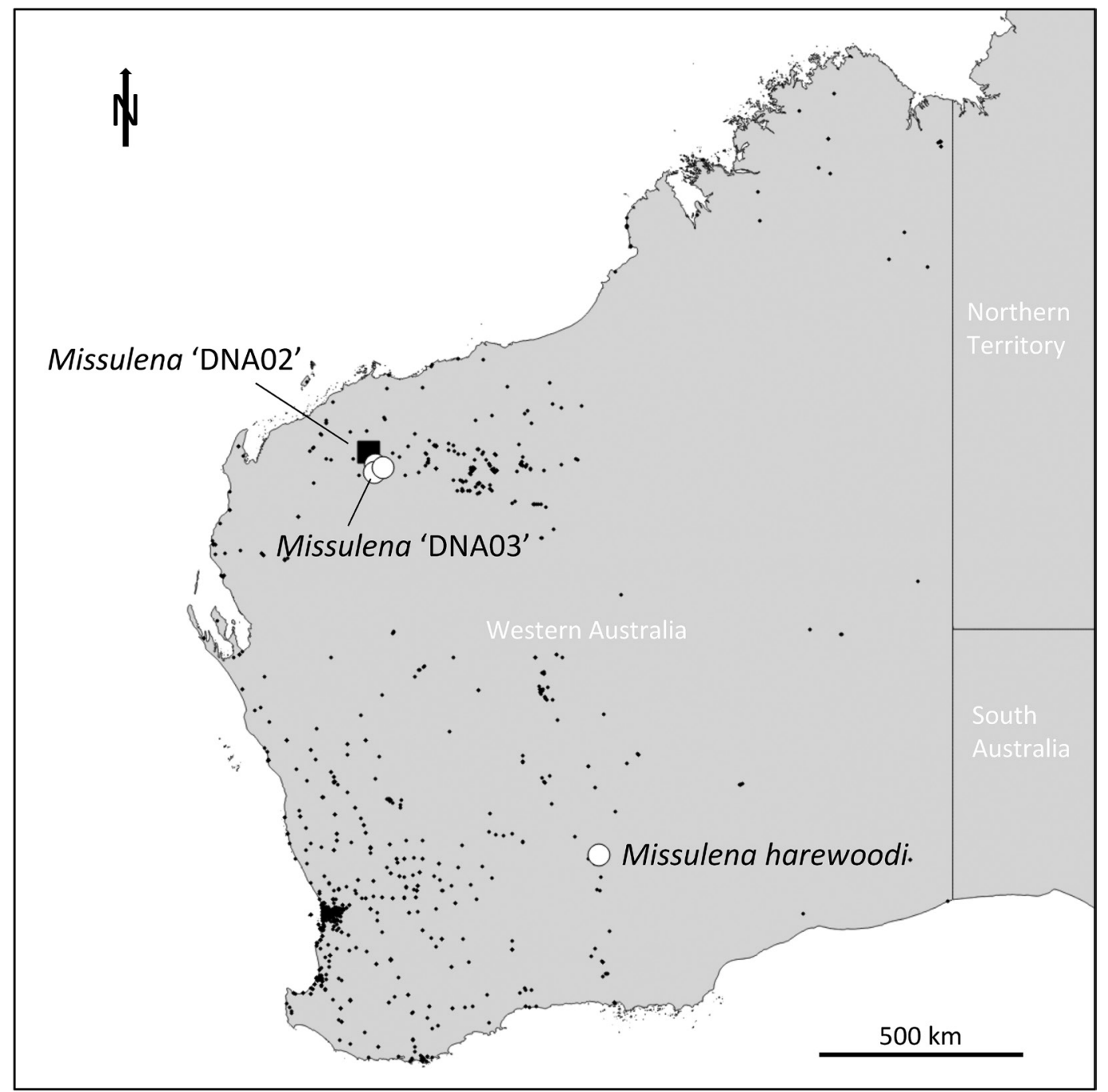

Figure 4. Distribution records of specimens sequenced at the COI gene fragment for this study (see Table 1). Small black dots represent all Missulena records from Western Australia (as downloaded from the Atlas of Living Australia - http://www.ala.org.au; accessed 10 April 2017).

us of about at least $100 \mathrm{~km}$ of its type locality, the only described species in the genus with the exception of the widespread M. occatoria (Walckenaer, 1805) (based on data of the Atlas of Living Australia; http://ala.org.au; accessed 10 April 2017). The species is yet another example of the extremely diverse invertebrate fauna of the semi-arid Goldfields region of Western Australia that is currently poorly studied in relationship to its invertebrate fauna when compared to other bioregions in Western Australia, e.g. the Pilbara (Durrant et al. 2010; McKenzie et al. 2009; Volschenk et al. 2010). Whilst comprehensive biological studies have been conducted in the Goldfields more than two decades ago, these rarely considered invertebrates (Biological Surveys Committee 1984; Keighery et al. 1995). Recent studies on terrestrial snails in the genus Bothriembryon Pilsbry, 1894 (Breure and Whisson 2012), millipedes in the genus Antichiropus Attems, 1911 (Car and Harvey 2013, 2014) and trapdoor spiders of the family Idiopidae Simon, 1892 (Rix et al. 2017) have highlighted both extreme diversity and endemism in invertebrates within the vast woodlands of the Goldfields and numerous unpublished reports as part of environmental impact assessments have supported these general findings for other taxonomic groups. The fact that $M$. harewoodi sp. $\mathrm{n}$. has never been sampled before near the regional centre of Kalgoorlie-Boulder and remains only known from a single specimen that was collected as by-catch during a vertebrate trapping survey, highlights the need for a comprehensive invertebrate fauna survey of this region that includes both its woodlands and isolated ranges of banded ironstone.

\section{Acknowledgements}

We thank Greg Harewood (Zootopia Environmental Sciences, Perth), for collecting the holotype specimen and bringing it to our attention. Laura Miglio, Anna Šestáková and Christo Deltshev provided helpful comments during the review process of this manuscript. Mark Castalanelli (Ecodiagnistics, Perth) helped troubleshooting some data submission issues. 


\section{References}

Biological Surveys Committee (1984) The biological survey of the Eastern Goldfields of Western Australia. Part 1: Introduction and methods. Records of the Western Australian Museum, Supplement 18: 1-19.

BoM (2017) Climate statistics for Australian locations. Commonwealth of Australia, Bureau of Meterology. http://www.bom.gov.au/climate/data [accessed 2 February 2017]

Breure ASH, Whisson CS (2012) Annotated type catalogue of Bothriembryon (Mollusca, Gastropoda, Orthalicoidea) in Australian museums, with a compilation of types in other museums. ZooKeys 195: 41-80. http://dx.doi.org/10.3897/zookeys.194.2721

Car CA, Harvey MS (2013) A review of the Western Australian keeled millipede genus Boreohesperus (Diplopoda, Polydesmida, Paradoxosomatidae). ZooKeys 290: 1-19. https://doi.org/10.3897/zookeys. 290.5114

Car CA, Harvey MS (2014) The millipede genus Antichiropus (Diplopoda: Polydesmida: Paradoxosomatidae), part 2: species of the Great Western Woodlands region of Western Australia. Records of the Western Australian Museum 29: 20-77. https://doi.org/10.18195/ issn.0312-3162.29(1).2014.020-077

Castalanelli MA, Teale R, Rix MG, Kennington J, Harvey MS (2014) Barcoding of mygalomorph spiders (Araneae: Mygalomorphae) in the Pilbara region of Western Australia. Invertebrate Systematics 28: 375-385. https://doi.org/10.1071/IS16061

Durrant BJ, Harvey MS, Framenau VW, Ott R, Waldock JM (2010) Patterns in the composition of ground-dwelling spider communities in the Pilbara bioregion, Western Australia. Records of the Western Australian Museum, Supplement 78: 185-204. https://doi. org/10.18195/issn.0313-122x.78(1).2010.185-204

EPA (2016) Technical Guidance. Sampling of short range endemic invertebrate fauna. Environmental Protection Authority, Perth, WA. http:// www.epa.wa.gov.au/sites/default/files/Policies_and_Guidance/Tech guidance- Sampling-SREs-Dec-2016.pdf [accessed 20 December 2016]

Faulder RJ (1995a) Systematics and biogeography of the spider genus Missulena Walckenaer. M.Sc. thesis. Department of Crop Sciences, Faculty of Agriculture, University of Sydney, Sydney, NSW.

Faulder RJ (1995b) Two new species of the Australian spider genus Missulena Walckenaer (Aranenae: Actinopodidae). Records of the Western Australian Museum, Supplement 52: 73-78.

Framenau VW, Baehr BC, Zborowski P (2014) A guide to the spiders of Australia. New Holland Publishers Pty Ltd, London, Sydney, Cape Town, Auckland.

Griswold CE, Ledford J (2001) Madagascar. Contributions to the study of biodiversity in Madagascar. Number 1: A monograph of the migid trap door spiders of Madagascar and review of the world genera (Araneae, Mygalomorphae, Migidae). Occasional Papers of the California Academy of Sciences 151: 1-120.

Harms D, Framenau VW (2013) New species of mouse spiders (Araneae: Mygalomorphae: Actinopodidae: Missulena) from the Pilbara region, Western Australia. Zootaxa 3637: 521-540. https://doi. org/10.11646/zootaxa.3637.5.2
Isbister GK (2004) Mouse spider bites (Missulena spp.) and their medical importance. Medical Journal of Australia 180: 225-227

Isbister GK, Gray MR (2004) Bites by Australian mygalomorph spiders (Araneae, Mygalomorphae), including funnel-web spiders (Atracinae) and mouse spiders (Actinopodidae: Missulena spp). Toxicon 43: 135-143. doi: https://doi.org/10.1016/j.toxicon.2003.11.009

Keighery GJ, McKenzie NL, Hall NJ (Eds) (1995) The biological survey of the eastern Goldfields of Western Australia: Part 11 Boorabbin-Southern Cross study area. Records of the Australian Museum, Supplement 49: 1-312.

Latreille PA (1806) Genera crustacearum et insectorum secundum ordinem naturalem in familias disposita, iconibus exemplisque plurimis explicata. Amand Koenig, Paris. https://doi.org/10.5962/bhl. title.34916

McKenzie NL, van Leeuwen S, Pinder AM (2009) Introduction to the Pilbara Biodiversity Survey, 2002-2007. Records of the Western Australian Museum, Supplement 78: 3-89. https://doi.org/10.18195/ issn.0313-122x.78(1).2009.003-089

Miglio LT, Harms D, Framenau VW, Harvey MS (2014) Four new mouse spider species (Araneae, Mygalomorphae, Actinopodidae, Missulena) from Western Australia. ZooKeys 410: 121-148. doi: https://doi.org/10.3897/zookeys.410.7156

Posada D, Crandall KA(1998) MODELTEST: testing the model of DNA substitution. Bioinformatics 14: 817-818. https://doi.org/10.1093/ bioinformatics/14.9.817

Rambaut A (2016) FigTree, version 1.4.3. http://ree.bio.ed.ac.uk/software/figtree/ [accessed 22 February 2017]

Rash LD, Birinyi-Strachan LC, Nicholson GM, Hodgson WC (2000) Neurotoxic activity of venom from the Australian eastern mouse spider (Missulena bradleyi) involves modulation of sodium channel gating. British Journal of Pharmacology 130: 1817-1824. https:// doi.org/10.1038/sj.bjp.0703494

Rix MG, Cooper SJB, Meusemann K, Klopfstein S, Harrison SE, Harvey MS, Austin AD (2017) Post-Eocene climate change across continental Australia and the diversification of Australasian spiny trapdoor spiders (Idiopidae: Arbanitinae). Molecular Phylogenetics and Evolution 109: 302-320. https://doi.org/10.1016/j.ympev.2017.01.008

Ronquist F, Huelsenbeck J, Teslenko M (2012) MrBayes: Bayesian Inference for Phylogeny v. 3.2.1. http://mrbayes.sourceforge.net/ download.php [accessed 15 March 2013]

Volschenk ES, Burbidge AH, Durrant BJ, Harvey MS (2010) Spatial distribution patterns of scorpions (Scorpiones) in the arid Pilbara region of Western Australia. Records of the Western Australian Museum, Supplement 78: 271-284. https://doi.org/10.18195/issn.0313122x.78(1).2010.271-284

Walckenaer CA (1805) Tableau des aranéides ou caractères essentiels des tribus, genres, familles et races que renferme le genre Aranea de Linné, avec la désignation des espèces comprises dans chacune de ces divisions, Paris.

World Spider Catalog (2017) World Spider Catalog. Natural History Museum Bern, Bern (Switzerland). http://wsc.nmbe.ch/ [accessed 27 January 2017] 